\title{
Comparative Characterization of Bacterial Communities in Moss-Covered and Unvegetated Volcanic Deposits of Mount Merapi, Indonesia
}

\author{
Annisa N. Lathifah ${ }^{1,2}$, Yong GuO ${ }^{2}$, Nobuo Sakagami ${ }^{1,2}$, Wataru Suda ${ }^{3}$, Masanobu Higuchi $^{4}$, \\ Tomoyasu Nishizawa ${ }^{1,2}$, Irfan D. PriJambada ${ }^{5}$, and Hiroyuki OHTA ${ }^{1,2 *}$ \\ ${ }^{1}$ United Graduate School of Agricultural Science, Tokyo University of Agriculture and Technology, 3-5-8 Saiwai-cho, Fuchu-shi, \\ Tokyo 183-8509, Japan; 'Ibaraki University College of Agriculture, 3-21-1 Chuo, Ami-machi, Ibaraki 300-0393, Japan; \\ ${ }^{3}$ Department of Computational Biology, Graduate School of Frontier Science, The University of Tokyo, Kashiwa, Japan; \\ ${ }^{4}$ Department of Botany, National Museum of Nature and Science, 4-1-1, Amakubo, Ibaraki, Japan; and ${ }^{5}$ Graduate School of \\ Biotechnology, University of Gadjah Mada, Yogyakarta, Indonesia
}

(Received March 14, 2019—Accepted May 15, 2019—Published online July 20, 2019)

Microbial colonization, followed by succession, on newly exposed volcanic substrates represents the beginning of the development of an early ecosystem. During early succession, colonization by mosses or plants significantly alters the pioneer microbial community composition through the photosynthetic carbon input. To provide further insights into this process, we investigated the three-year-old volcanic deposits of Mount Merapi, Indonesia. Samples were collected from unvegetated (BRD) and moss-covered (BRUD) sites. Forest site soil (FRS) near the volcanic deposit-covered area was also collected for reference. An analysis of BRD and BRUD revealed high culturable cell densities $\left(1.7-8.5 \times 10^{5} \mathrm{CFU} \mathrm{g}^{-1}\right)$ despite their low total $\mathrm{C}(<0.01 \%)$. FRS possessed high CFU $\left(3 \times 10^{6} \mathrm{~g}^{-1}\right)$; however, its relative value per unit of total $\mathrm{C}(2.6 \%)$ was lower than that of the deposit samples. Based on the tag pyrosequencing of $16 \mathrm{~S}$ rRNA genes, the BRD bacterial community was characterized by a higher number of betaproteobacterial families (or genus), represented by chemolithotrophic Methylophilaceae, Leptothrix, and Sulfuricellaceae. In contrast, BRUD was predominated by different betaproteobacterial families, such as Oxalobacteraceae, Comamonadaceae, and Rhodocyclaceae. Some bacterial (Oxalobacteraceae) sequences were phylogenetically related to those of known moss-associated bacteria. Within the FRS community, Proteobacteria was the most abundant phylum, followed by Acidobacteria, whereas Burkholderiaceae was the most dominant bacterial family within FRS. These results suggest that an inter-family succession of Betaproteobacteria occurred in response to colonization by mosses, followed by plants.

Key words: volcanic deposit, early bacterial community, succession, Betaproteobacteria

The role of microbes in the formation of new soil, followed by the development of terrestrial ecosystems, is one of the main topics of general ecology and soil biology. In this respect, newly emplaced substrates by volcanic eruptions and the soil of retreated glacier areas have been examined as suitable target materials. Previous studies revealed that prior to plant colonization, microbes rapidly colonized newly exposed substrates and that their communities may have played roles in early biogeochemical processes and soil development $(16,25,33,35,51)$. Kelly et al. (33) reported that 3-5 months after an eruption, Fimmvörðuháls lava flow (Eyjafjallajökull, Iceland) was colonized by a low-diversity microbial community dominated by Betaproteobacteria. This class of bacteria was related to non-phototrophic diazotrophs, such as Herbaspirillum spp., and chemolithotrophs, e.g. Thiobacillus. Several unvegetated, acidic volcanic deposits (3.5-6.0 years old) in the island of Miyake (Miyake-jima), Japan, harbored approximately $10^{6}$ cells (g dry weight ${ }^{-1}$ ) of autotrophic $\mathrm{Fe}$ (II) oxidizer communities represented by Acidithiobacillus spp. and Leptospirillum groups I, II, and III (16).

King (36) reported that reductant-rich volcanic deposits in hydrothermal and solfatara systems contained a number of chemolithotrophic bacteria, which were capable of exploiting high concentrations of inorganic substrates, particularly sulfides.

\footnotetext{
* Corresponding author. E-mail: hiroyuki.ohta.1494@vc.ibaraki.ac.jp;
} Tel: +81-29-228-8050; Fax: +81-29-228-8050.
This is the case for Fimmvörðuháls lava flow, in which early bacterial colonizers were found to be related to galena $(\mathrm{PbS})$ - and $\mathrm{H}_{2} \mathrm{~S}$-oxidizing Thiobacillus plumbophilus (33). Chemolithotrophy primarily occurs in reductant-poor volcanic ecosystems, in which facultative chemolithotrophs are known to oxidize CO, $\mathrm{H}_{2}$, or both for energy $(35,36)$. The study of a 1959 cinder deposit in Hawaii revealed a diverse community that comprised Cyanobacteria, Acidobacteria, and Alphaproteobacteria along with microorganisms that were specifically capable of $\mathrm{CO}$ and hydrogen oxidation when pioneering the deposit (65). The contribution of atmospheric trace gases in primary production was also reported for Antarctic desert soil (28). Furthermore, $\mathrm{H}_{2}$-oxidizing, facultative chemolithotrophic bacteria, e.g. Cupriavidus pinatubonensis and C. laharis, represented the main culturable bacterial population in the volcanic mudflow deposit of Mt. Pinatubo (Philippines) $(51,52)$.

Microbial succession across post-eruption chronosequences occurs well before plant colonization. A metagenomic analysis from an unvegetated site of Miyake-jima volcanic deposits (3.5-9.5 years old) revealed the abundance of a nitrogen fixation gene $(n i f H)$. This contributed as the main feature of the deposits and accounted for approximately $50 \%$ of nitrogen-cycling related genes. Hence, the composition of $\mathrm{N}_{2}$-fixing bacteria shifted from an obligate chemolithotrophic Fe (II)-oxidizing community (53) to heterotrophic and/or facultative lithotrophic diazotrophs, such as Burkholderia, Beijerinckia, and Leptothrix (17). In addition to new volcanic substrates, early microbial 
succession is well characterized in unvegetated and recently deglaciated soils $(49,54,70)$. A study on pre-plant stages (primary succession) in deglaciated soils of the high-Andean chronosequence showed that barren soils were colonized by a diverse community of Cyanobacteria. Moreover, a significant increase in cyanobacterial diversity corresponded with marked increases in the heterotrophic microbial biomass and soil enzyme activity (54). Furthermore, soil nitrogen fixation rates increased by almost two orders of magnitude during the first 4-5 years of succession and many years before the establishment of mosses, lichens, or vascular plants. The relative abundance of cyanobacterial populations increases with soil age, and its correspondence with the accretion of soil nitrogen pools in unvegetated soils also holds true for the emerging landscape near the receding Puca Glacier (southeast Peru) (49).

Microbial succession on newly exposed, unvegetated substrates is an important factor for early biogeochemical cycling and ecosystem development. However, plant colonization significantly alters the pioneer microbial community composition through carbon inputs in the form of root exudates and litter deposits $(2,20)$, which further facilitates ecosystem development. Glacial retreat areas have hosted many studies to examine shifts in microbial community structures in association with colonizer plants during early primary succession $(6,37)$. In the context of these studies, the trajectories of bacterial succession were generally selective shifts in Acidobacteria and Alphaproteobacteria. The population levels of these groups were low in the case of young glacial soils, but relatively abundant in vegetated soils. However, an opposite shift was recorded in the case of Betaproteobacteria. A study on actively retreating glaciers (6) reported significant differences in bacterial community compositions between the two glacial sites regardless of the successional stage. Despite differences in the geography, climate, and soil characteristics (chemical and physical) of the two sites, the soil bacterial community structure was observed to converge during plant succession. Across the successional stages, differences in community compositions were related to shifts in the relative abundances of specific bacterial phyla and sub-phyla. Compositional shifts at the Easton glacier reflected a decrease in initially abundant Betaproteobacteria with an increase in Acidobacteria, Bacteroidetes, and Verrucomicrobia. However, initially abundant candidate division WPS at the Mendenhall glacier declined during succession, whereas Acidobacteria increased in relative abundance.

To the best of our knowledge, only a few studies have investigated the relationship between pioneer plant colonization and microbial communities with respect to volcanic environments. One study examined scoria deposits in a sub-alpine desert on Mt. Fuji (Japan) using phospholipid fatty acid, denaturing gradient gel electrophoresis, and Biolog microplate analyses (69). The findings obtained showed a marked shift in the microbial community structure as a consequence of initial colonization by the pioneer herb, Polygonum cuspidatum followed by Larix kaempferi into the central areas of islandlike communities. Another study that focused on the recent Miyake-jima volcanic deposits along a vegetation gradient (23) revealed using $16 \mathrm{~S}$ rRNA pyrosequencing that the abundance of the Oxalobacteraceae family of Betaproteobacteria and Xanthomonadaceae family of Gammaproteobacteria increased in response to changes in the vegetation cover from grass to shrubs.

Mt. Merapi, an active stratovolcano of Indonesia, last erupted in 2010, which affected all areas around the mountain (5). The affected area, three years after the eruption, showed the appearance of moss-covered patches in volcanic deposits and, thus, provided a unique study site for clarifying the relationship between pioneer moss colonization and microbial communities. In the present study, samples were collected at moss-covered and unvegetated sites and analyzed for their bacterial community structures by the tag pyrosequencing of 16S rRNA genes. The results obtained provide insights into the succession of betaproteobacterial groups in response to moss colonization and facilitate our understanding of the relationship between early soil genesis and bacterial community.

\section{Materials and Methods}

\section{Site description and sampling}

Mt. Merapi, located near central Java (Indonesia), is an area of $300-400 \mathrm{~km}^{2}$ at 2,978 $\mathrm{m}$ above sea level (m.a.s.1.) (Fig. S1). Eruptions during the $20^{\text {th }}$ century that typically recurred every 4-6 years produced viscous lava domes that collapsed to form pyroclastic flows and subsequent lahars. These eruptions were relatively small, with eruptive volumes of $1-4 \times 10^{6} \mathrm{~m}^{3}$ and magnitude/volcanic explosivity indices of $1-3(7,57)$. The eruption in 2010 affected all areas around Mt. Merapi. Pyroclastic flow reached $4 \mathrm{~km}$ in the north, $11.5 \mathrm{~km}$ in the west, $7 \mathrm{~km}$ east, and approximately $15 \mathrm{~km}$ in the south reaching the Kaliadem area. Explosive bombs from the summit went in all directions (approximately $4 \mathrm{~km}$ ) and emitted large amounts of ash and gas into the atmosphere $(10,68)$. Volcanic ash deposits derived from the eruption were characterized by high contents of $\mathrm{SiO}_{2}$ (52.6-60.3 wt \%), $\mathrm{K}_{2} \mathrm{O}\left(1.99-2.99\right.$ wt \%), and $\mathrm{Al}_{2} \mathrm{O}_{3}(16.6-18.9 \mathrm{wt} \%)$ (68).

Our study sites were established on volcanic deposit-covered land (sites BR and BRU) and a forest site (FR). FR, along the Bebeng river at the foothills of Mt. Merapi, was selected as a reference site (Fig. S1). Site BR (07³4'39" S, $110^{\circ} 26^{\prime} 53^{\prime \prime}$ E, and 1,181 m.a.s.l.) was not vegetated. Site BRU $\left(07^{\circ} 34^{\prime} 39^{\prime \prime} \mathrm{S}, 110^{\circ} 26^{\prime} 51^{\prime \prime} \mathrm{E}\right.$, and 1,199 m.a.s.1.) was majorly inhabited by Campylopus umbellatus (moss) and partly by Athyrium sp. (lady fern), Imperata cylindrica (cogon grass), and Anaphalis javanica (Javanese edelweiss). Reference soils were sampled from site FR $\left(07^{\circ} 34^{\prime} 43^{\prime \prime} \mathrm{S}, 110^{\circ} 26^{\prime} 51^{\prime \prime}\right.$ E, and 1,199 m.a.s.1.), which was predominantly vegetated by Acacia decurrens (acacia), Schima wallichii (puspa), and Pennisetum purpureum (elephant grass). Samples were collected on March 6, 2013 from three points (depth of $30 \mathrm{~cm}$ ) at a $1-\mathrm{m}$ interval (Fig. S1). Samples were divided into two portions (in sterile plastic bags) and kept on ice. One sample bag was stored at $4{ }^{\circ} \mathrm{C}$ and the other at $-20^{\circ} \mathrm{C}$ for later bacteriological analyses (within one week of sampling) and DNA extraction, respectively. Roots and debris from forest soil samples (FRS) were removed prior to these analyses and DNA extraction.

\section{Chemical analysis and plate counts}

The total carbon (TC) and total nitrogen (TN) contents of the samples were measured using an NC analyzer (SUMIGRAPH NC-22F; Sumika Chemical Analysis Service, Tokyo, Japan). pH was assessed using the mass ratio 1:2.5 (sample: water). The volumetric water content was analyzed by drying the material at $105^{\circ} \mathrm{C}$ overnight. Regarding the bacterial plate count, nitrogen-free Ashby's mannitol medium ( $\mathrm{pH}$ 7.2) was used, containing (per L): mannitol (15 g), $\mathrm{CaCl}_{2} \cdot 7 \mathrm{H}_{2} \mathrm{O}(0.2 \mathrm{~g}), \mathrm{K}_{2} \mathrm{HPO}_{4}(0.2 \mathrm{~g}), \mathrm{MgSO}_{4} \cdot 7 \mathrm{H}_{2} \mathrm{O}(0.2 \mathrm{~g})$, $10 \%$ (w/v) $\mathrm{MoO}_{3}(0.1 \mathrm{~mL}), 10 \%(\mathrm{w} / \mathrm{v}) \mathrm{FeCl}_{3}(0.05 \mathrm{~mL})$, and agar $(15 \mathrm{~g})$. Sample dilutions plated in duplicate were incubated at $30^{\circ} \mathrm{C}$. 


\section{DNA extraction}

Total DNA was extracted in duplicate from $0.5-1.0 \mathrm{~g}$ of samples using ISOIL for Bead Beating (Nippon Gene, Tokyo, Japan) with skim milk powder (Wako, Osaka, Japan) according to the manufacturer's instructions with slight modifications (50). Additionally, for volcanic deposit samples from sites BR and BRU, DNA was extracted by the CTAB (hexadecyltrimethylammonium bromide) method (71) as described in our previous studies $(16,17,23)$. Duplicates of extracted DNA were pooled together and subjected to molecular analyses.

\section{Quantification of $16 S$ rRNA gene abundance}

The gene abundance of bacterial 16S rRNA was assessed by fluorescent quenching-based, real-time qPCR (40) using the primers Q-10f (5'-AGTTTGATCCTGGCTCAG-3') and 907R (5'-CCGT CAATTCCTTTRAGTTT-3') as described previously (50). The 5 '-end fluorescence-labeled primer, Q-10f, was purchased from J-Bio2 1 (Kisarazu, Japan). The PCR mixture $(30 \mu \mathrm{L})$ was composed of $2 \mu \mathrm{L}$ of template soil DNA, $0.5 \mu \mathrm{L}$ of $10 \mathrm{pmol} \mu \mathrm{L}^{-1}$ primers, Ex Taq polymerase, dNTPs, and $3 \mu \mathrm{L}$ of optimized $10 \times$ Ex buffer (Takara Bio, Kusatsu, Japan). qPCR was conducted on a PCR iCycler apparatus (Bio-Rad, Hercules, CA, USA) with the thermal cycle program of an initial cycle of $95^{\circ} \mathrm{C}$ for 2 min, 45 cycles of $95^{\circ} \mathrm{C}$ for $30 \mathrm{~s}, 52^{\circ} \mathrm{C}$ for $45 \mathrm{~s}$, and $72^{\circ} \mathrm{C}$ for $1.5 \mathrm{~min}$. The intensity of fluorescence quenching was measured to calculate the quenching rate as described by Kurata et al. (40). A standard curve was generated using the total genomic DNA of Escherichia coli and the copy number of 16S rRNA genes was calculated using the URI Genomics $\&$ Sequencing Center program (https://cels.uri.edu/gsc/cndna.html).

\section{$16 S$ rRNA-based tag-pyrosequencing}

The V1-V2 region of the $16 \mathrm{~S}$ rRNA gene (16S rDNA) was amplified using the universal primers $27 \mathrm{Fmod}$ and $338 \mathrm{R}$. Amplification conditions were set at $96^{\circ} \mathrm{C}$ for $2 \mathrm{~min}, 20$ cycles of $96^{\circ} \mathrm{C}$ for $30 \mathrm{~s}, 55^{\circ} \mathrm{C}$ for $45 \mathrm{~s}$, and $72^{\circ} \mathrm{C}$ for $1 \mathrm{~min}$ with a final extension of $72^{\circ} \mathrm{C}$ for $10 \mathrm{~min}$ on a 9700 PCR system (Life Technologies Japan, Tokyo, Japan) according to the protocol of Kim et al. (34). PCR products were confirmed by $2 \%$ agarose gel electrophoresis, purified by the Agencourt AMPure XP PCR purification kit (Beckman Coulter, Brea, CA, USA), and quantified using a Quant-iT PicoGreen dsDNA Assay Kit (Thermo Fisher Scientific, Waltham, MA, USA). A composite sample was prepared by pooling approximately equal amounts of the PCR amplicons from each sample. This was followed by pyrosequencing using Roche 454 GS FLX Titanium or 454 GS Junior (Roche Applied Science, Penzberg, Germany), according to the manufacturer's instructions.

\section{Sequence data processing and analysis}

The sequence data obtained from 454-pyrosequencing reads were analyzed using the pipeline developed by Kim et al. (34). In short, the raw sequence data obtained from 454 pyrosequencing was initially assigned to each sample on the basis of their barcode sequence. Reads with an average quality value $<25$ and those without both of the universal primer sequences were then filtered off. A total of 28,585 reads were ultimately recovered from raw data. In further analyses, 2,000 reads were randomly selected from each library. To define operational taxonomic units (OTUs), the clustering of 16S rDNA reads was performed with the UCLUST program (https://www. drive5.com/) using $96 \%$ pairwise identity as the cut-off. Representative sequences of each OTU were assigned a bacterial genus using a BLAST search (with $96 \%$ pairwise identity as the cut-off) against the Ribosomal Database Project (RDP, v10.27) and the reference genome database. The latter was constructed by adding 1,482 complete and 506 draft bacterial genomes from the NCBI FTP site (ftp://ftp.ncbi.nlm.nih.gov/) (34). OTUs, classified as the taxonomic information of a representative sequence with a high pairwise identity, were obtained by comparisons between the two databases. The weighted UniFrac distance was calculated from the phylogenetic tree of the representative sequences of an OTU by the PyCogent software library (38).

\section{Statistical analysis}

The properties (chemical and biological) and influence of the sampling site on bacterial diversity indices (Shannon, Inverse Simpson, ChaoI, and OTU number) were evaluated using ANOVA with Tukey's honestly significant difference (HSD) test to assess the significance of differences and clarify the rank order. Significance was defined at $P<0.05$. Similarities and differences in the bacterial community structure among the samples were examined using the weighted UniFrac distance with a principal coordinate analysis (PCoA) ordination technique. To assess whether a significant difference exists between CTAB-extracted and ISOIL-extracted communities, an analysis of molecular variance (AMOVA) in Mothur was performed using the sub-dataset of BRD and BRUD samples by two DNA extraction methods. A canonical correspondence analysis (CCA) was performed to examine the relationship between bacterial communities and environmental variables. The percentage abundance of bacterial families in each volcanic deposit and the soil sample library was used as the species input. The vegetation type (unvegetated and C. umbellatus moss) and chemical properties ( $\mathrm{pH}, \mathrm{TC}, \mathrm{TN}, \mathrm{C}: \mathrm{N}$ ratio, and water content) served as environmental inputs. Ordination plots of CCA results were performed using the function cca from the R package 'vegan' (http://cran.r-project.org/web/packages/vegan/ index.html). The relationship between each environment variable and bacterial communities was investigated using the function anova.cca from the R package 'vegan' to assess the significance of constraints.

\section{Phylogenetic tree}

The 16S rRNA gene sequences of OTUs were compared with those of the OTUs and type strains in the RDP and NCBI databases. Clustal $\mathrm{W}$ was used to perform a multiple sequence alignment. Phylogenetic trees were reconstructed in MEGA version 7 using neighbor joining with 1,000 bootstrap replicates. Genetic distances were calculated using the maximum composite likelihood model.

\section{Sequence data accession number}

Filtered pyrosequencing reads were deposited in the DDBJ Sequence Read Archive database under the accession number DRA002857.

\section{Results}

\section{Chemical characteristics, plate count of bacteria, and abundance of the 16S rRNA gene}

The chemical properties of volcanic deposit samples from sites BR (BRD), BRU (BRUD), and FR (FRS) are shown in Supplementary Table $\mathrm{S} 1$. The $\mathrm{pH}$ values of BRD and BRUD were similar to that of FRS and varied between 7.2-7.5. The $\mathrm{TC}$ and TN contents of BRD and BRUD were lower than those of FRS in three to four and two orders of magnitude, respectively (Table S1). Ashby's mannitol medium was used to estimate the population level of bacteria that was able to grow in nitrogen-free medium. Plate counts were approximately $1.7 \times 10^{5} \mathrm{CFU} \mathrm{g}^{-1}$ for BRD and $8.5 \times 10^{5} \mathrm{CFU} \mathrm{g}^{-1}$ for BRUD, which were markedly lower than that of FRS $\left(3.0 \times 10^{6} \mathrm{CFU} \mathrm{g}^{-1}\right)$. The quantification of 16S rRNA gene abundance supported the lower bacterial population density in BRD and BRUD than in FRS: 7.2 and $3.6 \times 10^{8}$ gene copies $\mathrm{g}^{-1}$ for the BRD and BRUD samples, respectively, vs. $8.0 \times 10^{10}$ gene copies $\mathrm{g}^{-1}$ for the FRS sample. The gene abundance of 16S rRNA in BRD and BRUD was similar to that $\left([2.64 \pm 1.70] \times 10^{8}\right.$ gene copies $\mathrm{g}^{-1}$ ) at the bare sites of Hawaiian volcanic deposits (66). 


\section{Similarity and diversity of bacterial communities}

Nearly $100 \%$ (99.98\%) of 26,000 reads from 13 sample libraries (constituted by 9 ISOIL-DNA samples of BRD, BRUD, and FRS triplicates and 4 CTAB-DNA samples: two out of BRD and BRUD triplicates) were annotated and assigned bacterial phyla. PCoA was performed on the 13 libraries to estimate similarities or differences among the bacterial communities. The results obtained and shown in Fig. 1 indicate the distinct clustering of bacterial communities across samples. When tested by AMOVA, no significant differences were observed between the ISOIL-DNA and CTAB-DNA libraries of BRD and BRUD $(P=0.448)$. Therefore, ISOIL-DNA libraries were selected for subsequent analyses. A total of 18,000 reads were classified into 2,879 OTUs. The average number of OTUs recorded for the bacterial communities of BRD, BRUD, and FRS were 397, 287, and 751, respectively; suggesting the bacterial community diversity in BRUD to be the lowest (Table S2). These results were supported by the Shannon, Inverse Simpson, and ChaoI indices calculated from pyrosequencing data (Table S2) and rarefaction curves (Fig. S2).

\section{Comparison of the bacterial community structure}

Proteobacteria was the most abundant phylum observed in the bacterial community of FRS (mean percent relative abundance of triplicate samples: $50 \%)$, BRD (63\%), and BRUD (66\%) (Fig. 2). Firmicutes was the second most abundant group in the BRD and BRUD communities (8 and 15\%, respectively), which was followed in order by Actinobacteria ( $9 \%$ for both). On the other hand, Acidobacteria (19\%) and Actinobacteria (9\%) constituted the second major groups in the FRS community. Betaproteobacteria was the most prominent bacterial class of Proteobacteria found in the BRD

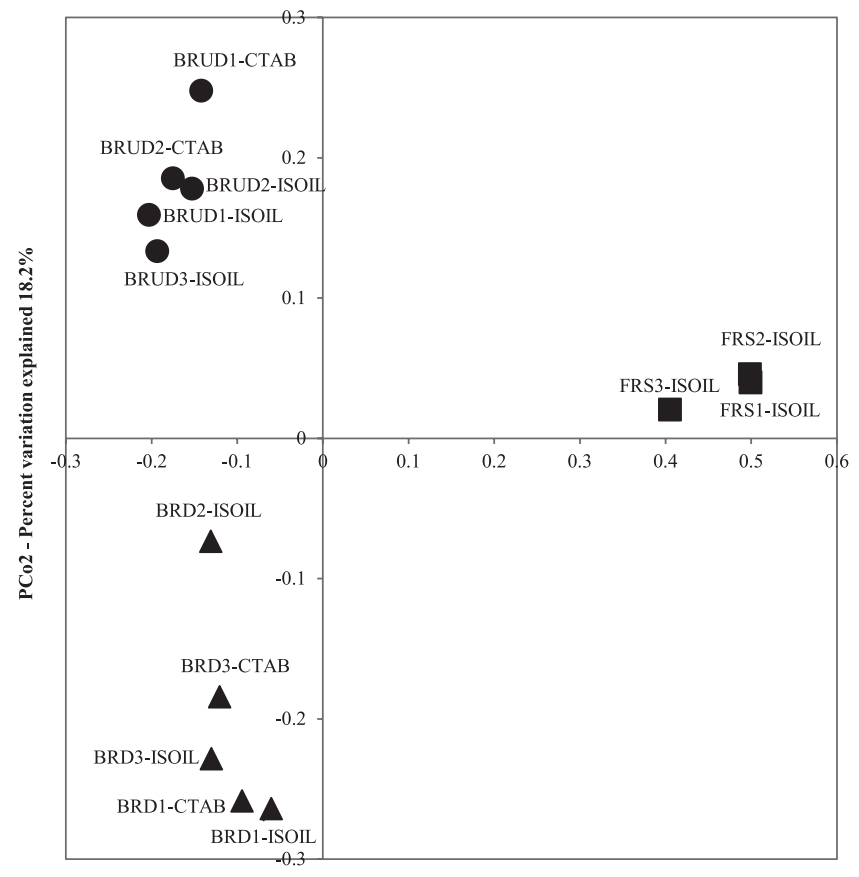

PCo1 - Percent variation explained $40.0 \%$

Fig. 1. Principal coordinate analysis (PCoA) plots of bacterial communities of volcanic deposit $(\boldsymbol{\Delta}, \bullet)$ and soil ( $\boldsymbol{\bullet})$ samples by weighted UniFrac.
(31\%) and BRUD (35\%) communities. The relative abundances of alpha-, beta-, gamma-, and deltaproteobacterial classes (11-18\%) were observed in the FRS community (Fig. 2).

Comparisons of minor bacterial phyla (relative abundance: $<2 \%$ ) also indicated differences between the BRD/BRUD and FRS bacterial communities. The Deinococcus-Thermus group was only found in the BRD and BRUD communities. The phylum Cyanobacteria was present at a relatively higher abundance in the BRD and BRUD (0.8-2\%) communities than in the FRS community $(0.1-0.4 \%)$. The abundance of the phylum Thermotogae appeared to be higher in the BRUD community $(1.5 \%)$ than in the BRD and FRS communities $(0.2 \%)$.

Further examinations of bacterial OTUs revealed that $89.5 \%$ were assigned to 189 known families. Fig. 3 shows the major bacterial families (41 families; with relative abundance $>1 \%$ ), comprising the top 11,14 , and 16 families of the BRD, BRUD, and FRS communities, respectively. The BRD bacterial community was characterized by a high relative abundance of Methylophilaceae, Leptothrix (Burkholderiales incertae sedis), and Sulfuricellaceae of the class Betaproteobacteria; accounting for $9.8,5.5$, and $3.8 \%$, of total OTUs, respectively. The family Sinobacteriaceae of the class Gammaproteobacteria represented the most prominent group not only in BRD (14.2\%), but also in BRUD (13.7\%) and FRS (7.5\%) (Fig. 3A). The predominant Betaproteobacteria of the BRUD bacterial community were the members of Oxalobacteraceae $(13.5 \%)$, Comamonadaceae (5.7\%), and Rhodocyclaceae (4.8\%), which were different from those in the BRD community (Fig. $3 \mathrm{~B})$. In contrast to the BRD and BRUD communities, the FRS bacterial community was characterized by the appearance of Acidobacteria families, such as Acidobacteriaceae (5.6\%), Holophagaceae (3.5\%), and Solibacteraceae (3.3\%) (Fig.

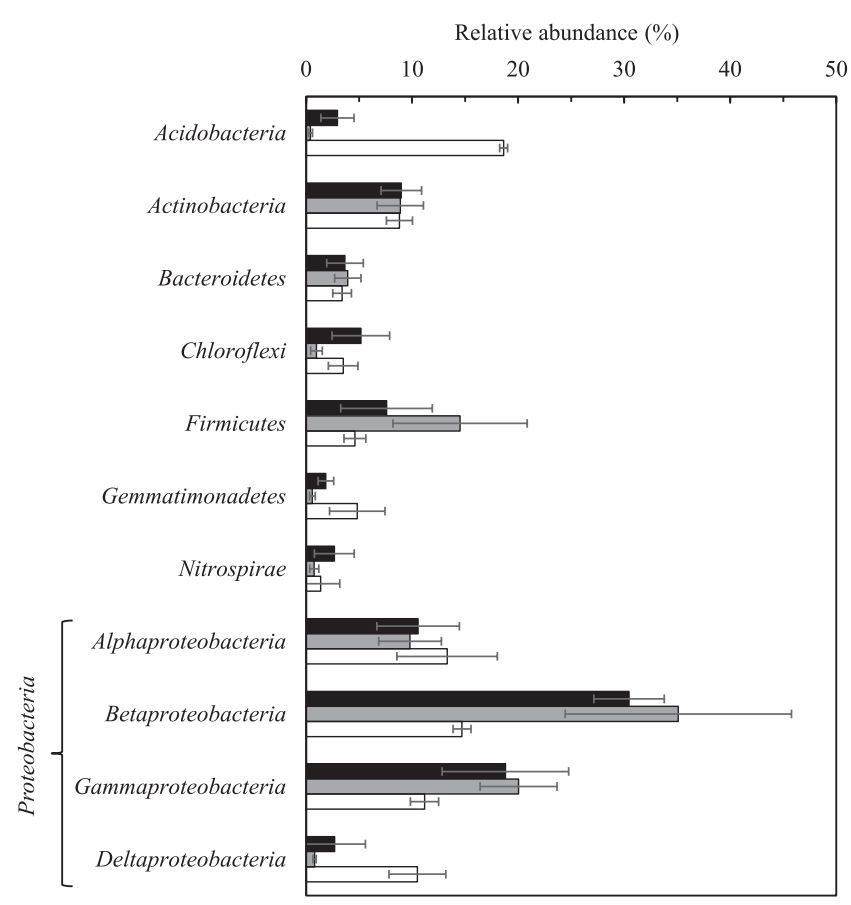

Fig. 2. Relative abundance of major phyla and classes of Proteobacteria in volcanic deposits ( $\square$, BRD; $\square$, BRUD) and the forest soil ( $\square$ ). Error bars indicate standard deviations $(n=3)$. 


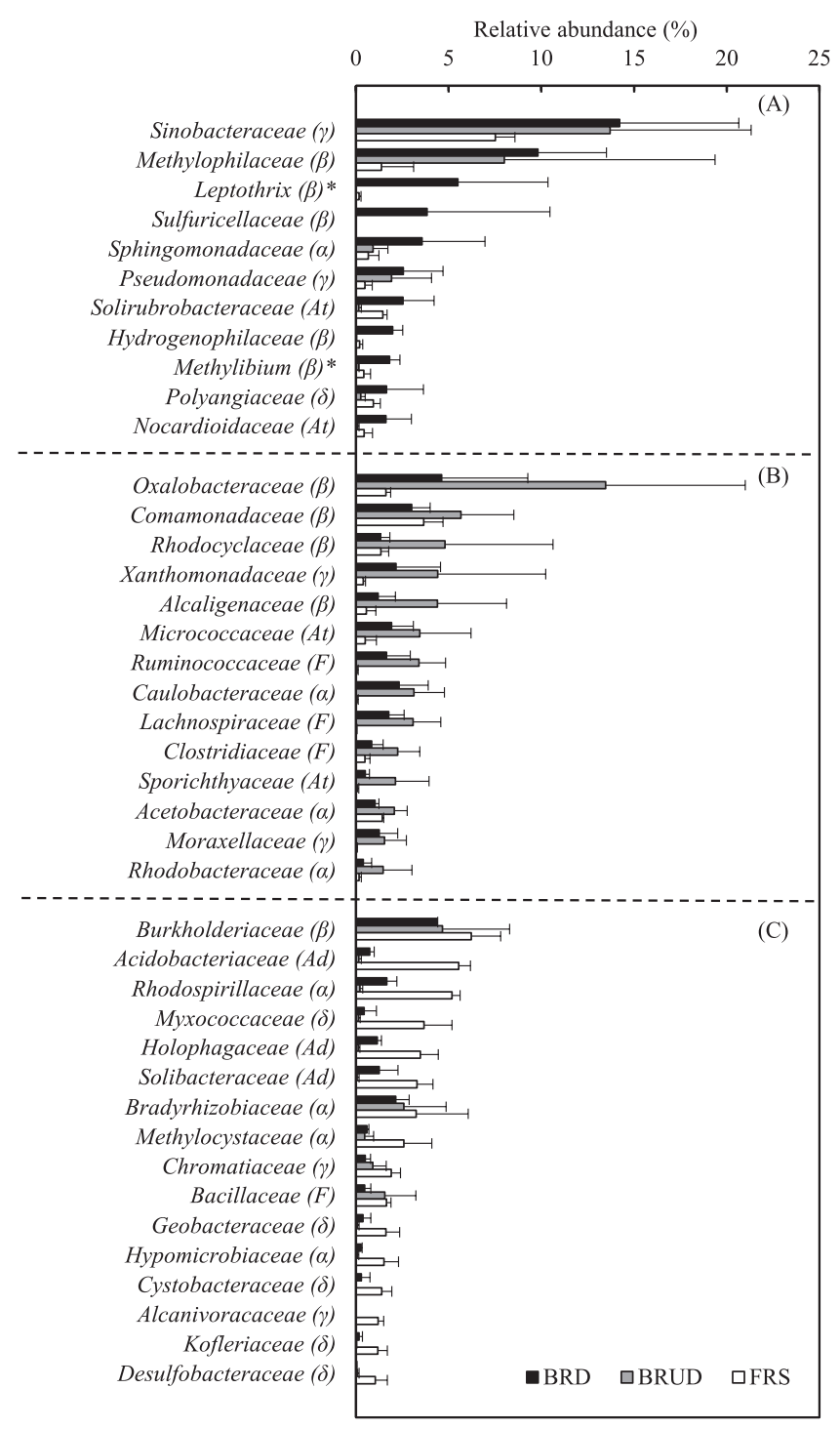

Fig. 3. Major families with relative abundance greater than $1 \%$. Grouping of the top 11,14 , and 16 families in the bacterial communities of BRD (A), BRUD (B), and FRS (C), respectively. The family name is followed by letter(s) in parentheses, showing the phyla Acidobacteria $(A d)$, Actinobacteria $(A t)$, and Firmicutes $(F)$, and the classes Alphaproteobacteria $(\alpha)$, Betaproteobacteria $(\beta)$, Gammaproteobacteria $(\gamma)$, and Deltaproteobacteria $(\delta) .{ }^{*}$ Burkholderiales inserta sedis.

3C). Rhodospirillaceae (5.2\%) belonging to the class Alphaproteobacteria and Myxococcaceae $(3.7 \%)$ of the class Deltaproteobacteria were specifically abundant in the FRS community. In contrast, the family Burkholderiaceae of Betaproteobacteria was present in BRD and BRUD (4.4$4.7 \%)$ and also in FRS communities (6.2\%). Similar results were observed for the family Bradyrhizobiaceae (Alphaproteobacteria) with 2.2, 2.6, and 3.3\% abundance in the BRD, BRUD, and FRS bacterial communities, respectively.

\section{Relationship between the bacterial community and environment factors}

CCA was performed to reveal possible links between environmental factors and known bacterial families. The statistical test by ANOVA showed correlations between water content, TC, TN, and the $\mathrm{C}: \mathrm{N}$ ratio and bacterial com- munities. The relationship between environmental factors and specific bacterial families was shown in Fig. 4. Positive correlations between Oxalobacteriaceae, Xanthomonadaceae, Micrococcaceae, Alcaligenaceae, and Caulbacterceae and the moss, C. umbellatus, were observed in site BRUD, whereas Rhodospirillaceae and Acidobacteriaceae correlated with increases in $\mathrm{TC}, \mathrm{TN}$, the $\mathrm{C}: \mathrm{N}$ ratio, and water content in site FRS. However, $\mathrm{pH}$ did not significantly affect bacterial families in the present study sites.

\section{Discussion}

Newly exposed volcanic deposits served as habitats for microorganisms in spite of lacking even detectable amounts of organic matter and vegetation $(16,19,25,35,47)$. To the best of our knowledge, bare volcanic deposits ( 3 months- 8.5 years old) harbor $10^{6}-10^{8} \mathrm{~g}^{-1}$ of bacteria (direct cell count) and approximately $10^{6} \mathrm{~g}^{-1}$ of culturable bacteria $(16,33)$. Our plate count data $\left(10^{5} \mathrm{~g}^{-1}\right.$ for BRD) was consistent with previous findings and suggested that bacterial colonization was not strictly dependent on carbon and nitrogen availabilities in deposits. In other words, a deficiency in organic nutrients may result in the significant occurrence of chemolithotrophy, thereby yielding a fully detectable bacterial biomass, as described by King (36). Alternatively, microbial phototrophy may occur in new terrestrial substrates, as demonstrated in recently deglaciated soils that harbored Cyanobacteria as pioneer microbes $(32,45,54)$. However, in our BRD and BRUD samples, the population level of Cyanobacteria was as low as $0.3-0.4 \%$. Very low levels of Cyanobacteria have also been found in previously examined volcanic deposits $(16,23,25,33,35)$. The reasons for this low cyanobacterial abundance currently remain unclear.

The bacterial community of the unvegetated Mt. Merapi volcanic deposit (BRD) was predominated by Betaproteobacteria (Fig. 2). The major families of this class with relative abundance of more than 3\% were as follows: Methylophilaceae $(9.8 \%)$, Leptothrix (family Burkholderiales incertae sedis) (5.5\%), and Sulfuricellaceae (3.8\%) (Fig. 3A). Further examinations revealed that the majority of OTUs of Methylophilaceae belonged to the genus, Methylotenera (Fig. S3). The genus Methylotenera comprises two species: Methylotenera mobilis (29) and $M$. versatilis (30). M. mobilis is described as an obligate methylamine-utilizing bacterium, whereas $M$. versatilis is a facultative methylotroph. The type strains of these species were isolated from the sediments of Lake Washington, USA. using media supplemented with methylamine. In nature, methylamine is found in the breakdown of dead animals or plant matter; however, it is not expected to exist in organic matter-poor volcanic deposits. Interestingly, Eyice et al. (14), by combining stable isotope probing and metagenomics, identified Methylotenera and Thiobacillus as the main consumers of dimethylsulfide (DMS), an atmospheric trace gas present in terrestrial environments. Annual DMS emissions into the atmosphere from terrestrial ecosystems are estimated to be $3.8 \mathrm{Tg}$ (64). As described by King (36), volcanic deposits lacking significant levels of organic matter represent a habitat that may harbor chemolithotrophic trace gas oxidizers, which are capable of deriving substrates for energy generation from the atmosphere. Therefore, the occurrence of Methylophilaceae 

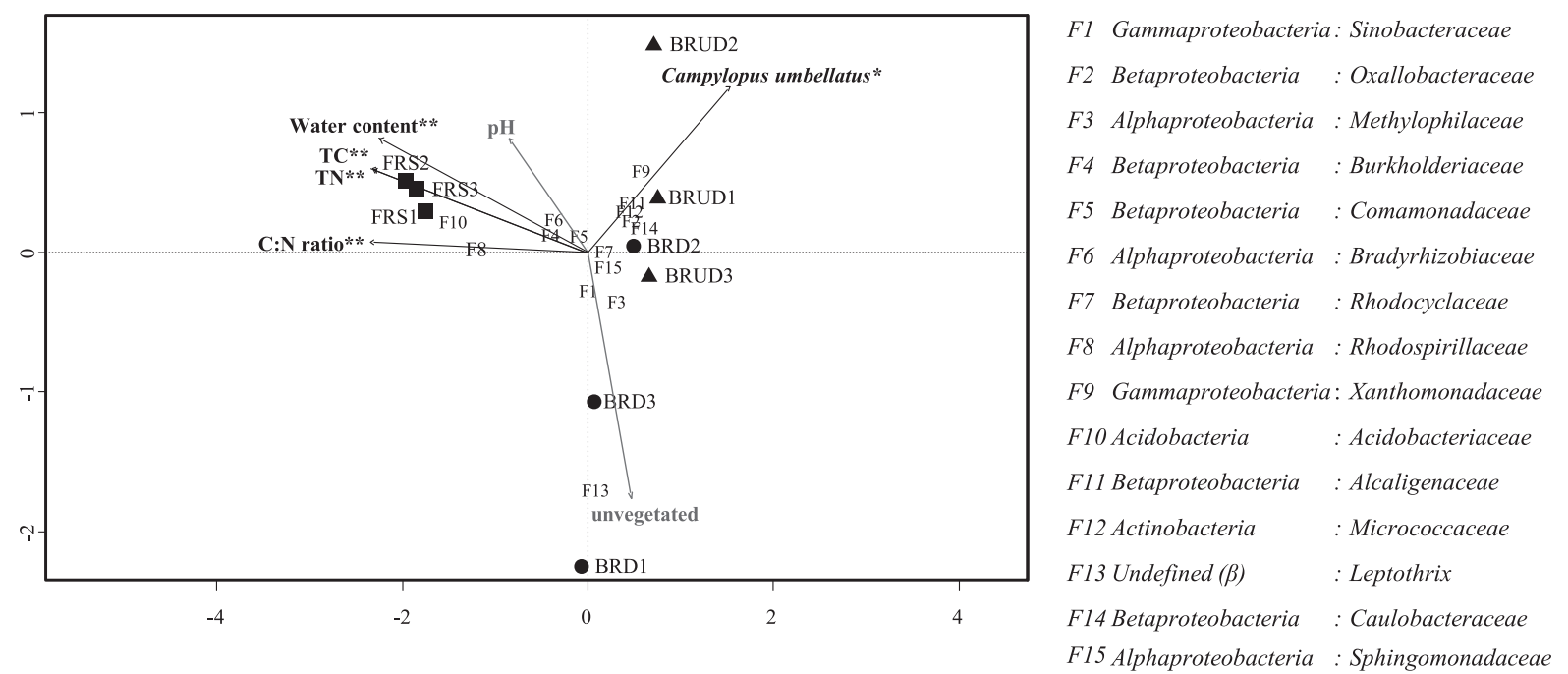

Fig. 4. Canonical correspondence analysis (CCA) ordination plots of bacterial communities of volcanic deposits $(\boldsymbol{\Delta}$, $\bullet)$ and results of the analysis of environmental factors affecting bacterial distribution. The direction of the arrows indicates an increasing value of environmental parameters and the arrow length indicates the degree of the correlation with the represented axis. The numbers correspond to bacterial families (given in the key on the right), which are ranked according to their abundance. The asterisk symbol $(*, 0.01<P$ value $<0.05 ; * *, 0.001<P$ value $<0.01)$ represents a correlation between the environmental factor and bacterial community, tested by ANOVA.

and Hydrogenophilaceae, including Thiobacillus, in the BRD community will be explained by their growth at the expense of atmospheric DMS as a carbon and energy source.

The OTU (OTU00084) of Sulfuricellaceae (relative abundance: $3.8 \%$ in BRD) is related to the cluster of the genus Sulfuriferula, a sulfur-oxidizing, chemolithotrophic bacterium (62). The sequence of this OTU (304 nucleotides length) is identical to the partial sequence of the uncultured betaproteobacterium clone, OY07-C004, which was recovered from a seven-year-old Miyake-jima volcanic deposit (16) (Fig. S3). This finding suggests that this OTU group is a common and early colonizer of the volcanic environment. The genus Sulfuriferula has so far been represented by only three species: S. multivorans, S. plumbophilus (formerly T. plumbophilus), and $S$. thiophila. Amongst them, S. thiophila may grow using hydrogen as the electron donor (63) and, thus, is expected to exist by consuming atmospheric $\mathrm{H}_{2}$ (mixing ratio: $550 \mathrm{ppbv}$ ) (9) in carbon-poor environments, as observed in Mt. Kīlauea volcanic deposits (35). As shown in Fig. S3, OTU00134 (relative abundance: $4.3 \%$ ) specific to BRD was closely related to the sequence of the arsenite-oxidizing bacterium, Leptothrix sp. S1.1, which was isolated from the settling pond sediments of As- and Fe-containing mine-drainage water (3). However, we do not have any data on As (III) or Fe (III) oxidation in Mt. Merapi volcanic deposits.

The family Sinobacteriaceae (Gammaproteobacteria) was the most abundant group in the BRD community (Fig. 3A). In the phylogenetic tree of Sinobacteriaceae (Fig. S4), sequences of the major OTUs (OTU00073 and OTU01094) clustered with the genus, Nevskia. One of them (OTU00073) showed similarity to the partial sequence of Nevskia sp. KP1-11, isolated from an unvegetated volcanic deposit (at a distance of $20 \mathrm{~m}$ from the seashore) in the south of Miyake-jima (46). Nevskia ramosa isolates grew at the air-water interface and benefitted by trapping ammonia from the air despite the absence of nitrogenase activity (18). This may explain the presence of Nevskia in unvegetated volcanic deposit(s). The most abundant sequence (OTU00047; relative abundance: 9.7\% in BRUD community) in Sinobacteriaceae clustered with an uncultured bacterium clone (SC6-RK103) that was recovered from white areas in the mural paintings of Etruscan tombs (11). This clone was annotated as Panacagrimonas perspica (26), isolated from soil sampled from a ginseng field with an identity of $97 \%$. No further information is available for OTU00073.

An analysis of the BRUD bacterial community revealed betaproteobacterial succession from Leptothrix and Sulfuricellaceae to Oxalobacteraceae, Comamonadaceae, and Rhodocyclaceae. However, Methylophilaceae was still predominant (8\%) in BRUD (Fig. 3B). The most abundant bacterial family in BRUD, Oxalobacteraceae, accounted for $13.7 \%$ of the total community, which was reported to harbor root-colonizing, heterotrophic bacteria in a succession of bacterial communities during early plant development (21, 22). Similarly, a positive correlation ( $P$ value, 0.04$)$ between Oxalobacteraceae and C. umbellatus (moss) was noted in the present study, as shown by CCA with the ANOVA test (Fig. 4). The phylogenetic analysis of Oxalobacteraceae OTUs from BRUD in the present study revealed that the major OTU (OTU00008) accounted for $9.6 \%$ of the BRUD community and was clustered within the genus Massilia that included the following: M. timonae R2-11, M. plicata LB-U, and $M$. dura $16^{\mathrm{T}}$ (Fig. S4). Amongst these, M. timonae R2-11 and M. plicata LB-U were described as moss-associated bacteria (59). The second major OTU (OTU00143; relative abundance: 1.6\%) was closely related to Undibacterium oligocarboniphilum EM $1^{\mathrm{T}}$; a novel bacterium, capable of growing in low carbon substrate concentrations (13) (Fig. S4). Another OTU (OTU00091, 0.7\%) was clustered with weathering-associated Janthinobacterium agaricidamnosum NBRC $102515^{\mathrm{T}}$ (43, 60, 61) (Fig. S5).

In ecological succession, mosses are the pioneering species and important drivers of the biogeochemical cycles of the ecosystem $(1,41,55)$. Mosses contribute carbon to support 
soil and also provide a microhabitat for a wide diversity of microorganisms (44). Campylopus, a moss, has been reported as the pioneer vegetation of volcanic areas $(4,8,42)$. Jackson (27) reported that mosses, presumably with the assistance of associated microorganisms, strongly enhanced the chemical weathering of granitic genesis on which they were growing and also mediated the formation of soil containing various biogenic secondary minerals. This may have occurred in the BRU site due to the association of Campylopus_(moss) with the above-described bacteria (Massilia). Weathering through the moss-bacterium relationship warrants further study.

The occurrence of OTUs affiliated with Alcaligenaceae and Rhodocyclaceae (OTU00631 and OTU00228, respectively) cannot be explained as simply as that of Oxalobacteraceae OTUs. OTU00631 is closely related to the uncultured bacterium clone C SML 53 (Fig. S5), which was recovered from the surface microlayer of the water column in Coldspring Lake, Canada (12). The latter is a small $\left(<1 \mathrm{~km}^{2}\right)$, shallow (average depth $\sim 3 \mathrm{~m}$, maximum depth $\sim 7 \mathrm{~m}$ ), wetland-associated, highly organic, and Fe-rich soft water Canadian Shield lake. The surface microlayer of the lake was assumed to harbor arsenite-, Fe (II)-, and thiosulfate-oxidizing bacteria. Similarly, the sequence of OTU00228 in Rhodocyclaceae was related to the partial sequence of the uncultured bacterium clone SX2-1 from a sample of Fe- and S-containing wasted bioleaching liquid (pH 3.0) (Fig. S5) (24). In relation to these sulfur-rich environments, it is noteworthy that OTU00228 is grouped with the clade of Sulfuritalea hydrogenivorans DSM $22779^{\mathrm{T}}$, which grows chemolithoautotrophically under anoxic conditions by oxidizing reduced sulfur compounds and hydrogen (39) (Fig. S5). These findings suggest that bacteria corresponding to Alcaligenaceae and Rhodocyclaceae OTUs perform chemolithotrophic metabolism.

The FRS bacterial community is predominated by the families of Acidobacteria, Alphaproteobacteria, Gammaproteobacteria, and Deltaproteobacteria. No other Betaproteobacteria, except for the most abundant family Burkholderiaceae (6.2\%), was ranked in the top 14 families. Burkholderiaceae was also one of the major members in the BRD (4.4\%) and BRUD (4.7\%) communities. To compare the lower taxonomic level of Burkholderiaceae OTUs among the three sites, a phylogenetic tree analysis was conducted for OTUs with a relative abundance of $>0.1 \%$ at any of the sites (Fig. S6). Amongst the 20 OTUs examined, 9 were only found in FRS, whereas 4 were specific to BRD and/or BRUD. Two OTUs were detected in all sites and the others were found in BRD+FRS or BRUD+FRS. This result suggests that approximately half of the members of Burkholderiaceae were new when appearing during the change from volcanic deposits to soil. The sequence of OTU00241, specific to BRD (relative abundance: $0.2 \%$ ) and BRUD (2.6\%), is identical to the partial 16S rRNA gene sequence of Ralstonia sp. ML7 that was isolated from soil and was able to degrade the aliphatic polyesters, poly ( $\varepsilon$-caprolactone) and poly (hexamethylene carbonate) (58). The probable existence of such a polyester-degrading bacterium in volcanic deposits cannot currently be explained. However, this may be expected based on previous findings showing the isolation of 4-dichlorophenoxyacetic acid (2,4-D)-degrading bacteria from pristine environments with no history of 2,4-D exposure (31). Weber and King (67) iso- lated novel CO-oxidizing Paraburkholderia and Burkholderia from Mt. Kîlauea volcanic deposits (Hawaii). Our Merapi OTUs were not clustered with them (Fig. S6).

The phylum Acidobacteria is one of the most abundant soil bacteria and Acidobacteria subgroups 1, 3, 5, and 6 collectively account for $87 \%$ of the total Acidobacteria community in forest soils of the western Brazilian Amazon (48). The majority of acidobacterial OTUs in FRS belonged to Acidobacteria subgroup 1 (Gp 1) (Fig. S7). Fierer et al. (15) proposed oligotrophic and copiotrophic phyla based on the findings of molecular analyses for a total of 71 unique soils, representing soil and site characteristics in the USA. In their study, bacteria belonging to Acidobacteria were the most abundant in soils with very low resource availability (oligotrophic attributes). However, the relative abundances of Betaproteobacteria and Bacteroidetes were the highest in soils with high carbon availability (copiotrophic attributes). In their discussion citing autotrophic ammonia oxidizers in Betaproteobacteria, every member of Acidobacteria and Betaproteobacteria was not distinctly oligotrophic or copiotrophic. This is also the case for the bacterial community of new soils lacking significant amounts of organic nutrients, such as the Mt. Merapi volcanic deposits of the present study. Furthermore, Castle et al. (6) analyzed microbial community convergence across actively retreating glaciers and reported that bacterial community differences strongly correlated with discriminative shifts in Acidobacteria (a relatively abundant member of mature forest soils that was present at a low abundance in young glacial soil). The opposite was true for Betaproteobacteria. To clarify the relationship between these groups in more detail, an attempt was made to calculate the ratio of Betaproteobacteria to Acidobacteria from the data of earlier studies on volcanic

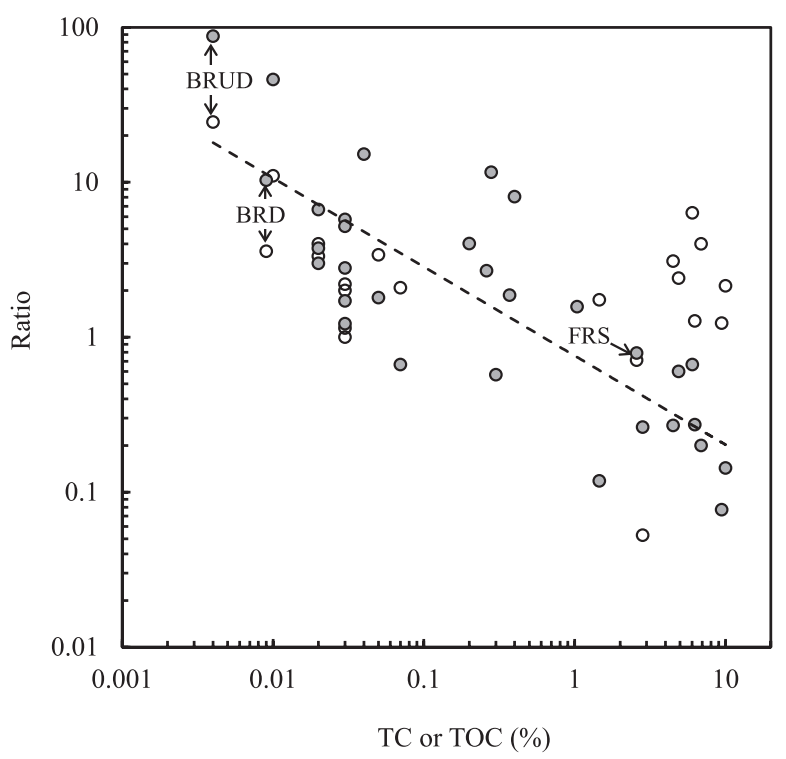

Fig. 5. Ratios of Alphaproteobacteria to Acidobacteria (०) and Betaproteobacteria to Acidobacteria (๑) in bacterial communities of volcanic deposits and environmental soils.

The plots of this study (BRD, BRUD, and FRS) are shown with arrows. The other plots were calculated from the data of Castle et al. (6), Fujimura et al. (16), Guo et al. (23), and Summers et al. (56). The relationship between TC or TOC (total organic carbon) and the ratio of Betaproteobacteria to Acidobacteria is approximated as a broken line: $y=0.76 x^{-0.58}\left(r^{2}=0.661\right)$. 
deposits, deglaciated soils, and other newly exposed substrates. As shown in Fig. 5, plots of the ratio against the corresponding TC or total organic carbon (TOC) appear to show a negative relationship approximated as $y=0.76 \quad x^{-0.58} \quad\left(r^{2}=0.661\right)$, suggesting the abundance of Betaproteobacteria in lower carbon availability. As a reference, plots of the ratio of Alphaproteobacteria to Acidobacteria are not clearly dependent on TC or TOC (Fig. 5). As discussed above, the class Betaproteobacteria comprises various members that perform chemolithotrophic growth by using atmospheric trace gases and proliferates in association with pioneer mosses. Therefore, the ecological attributes of Betaproteobacteria appear to be important in early soil genesis and ecosystem development as well as in soils with high C availability (15).

In summary, the present results indicate that a phylogenetically diverse microbial community developed in Mt. Merapi volcanic deposits three years after the 2010 eruption and early colonists were mostly members of Betaproteobacteria. By comparing the bacterial communities on unvegetated and moss-covered deposits, we may assume that an inter-family succession of Betaproteobacteria occurred from chemolithotrophic to moss-associated groups. Further studies involving the isolation and characterization of culturable bacteria are now in progress to obtain more detailed information on bacterial contributions to early soil genesis.

\section{Acknowledgements}

We thank Dwita Nur Restiani M.Sc. at the Department of Geoinformation for spatial planning and disaster risk management, UGM for technical help presenting the sampling location map. This work was partially supported by a JSPS KAKENHI Grant (16H02932).

\section{References}

1. Bansal, S., M. Nilsson, and D.A. Wardle. 2012. Response of photosynthetic carbon gain to ecosystem retrogression of vascular plants and mosses in the boreal forest. Oecologia 169:661-672.

2. Bardgett, R.D., W.D. Browman, R. Kaufmann, and S.K. Schmidt. 2005. A temporal approach to linking aboveground and belowground ecology. Trends Ecol. Evol. 20:634-641.

3. Battaglia-Brunet, F., Y. Itard, F. Garrido, F. Delorme, C. Crouzet, C. Greffié, and C. Joulian. 2006. A simple biogeochemical process removing arsenic from a mine drainage water. Geomicrobiol. J. 23:201-211.

4. Broady, P., D. Given, L. Greenfield, and K. Thompson. 1987. The biota and environment of fumaroles on Mt. Melbourne, Northern Victoria Land. Polar Biol. 7:97-113.

5. Camus, G.A., A. Gourgaud, P.-C Mossand-Berthommier, and P.-M Vincent. 2000. Merapi (Central Java, Indonesia): An outline of the structural and magmatological evolution, with a special emphasis to the major pyroclastic events. J. Volcanol. Geotherm. Res. 100:139-163.

6. Castle, S.C., D.R. Nemergut, A.S. Grandy, J.W. Leff, E.B. Graham, E. Hood, S.K. Schmidt, K. Wickings, and C.C. Cleveland. 2016. Biogeochemical drivers microbial community convergence across actively retreating glaciers. Soil Biol. Biochem. 101:74-84.

7. Caudron, C., D.K. Syahbana, T. Lecocq, V.V. Hinsberg, W. McCausland, A. Triantafyllou, T. Camelbeeck, A. Bernard, and Surono. 2015. Kawah Ijen volcanic activity: a review. Bull. Volcanol. (Heidelberg) 77:16.

8. Clarkson, B.R., and B.D. Clarkson. 1995. Recent vegetation changes on Mount Tarawera, Rotorua, New Zealand. N.Z. J. Bot. 33:339-354.

9. Conrad, R. 1996. Soil microorganism as controllers of atmospheric trace gases $\left(\mathrm{H}_{2}, \mathrm{CO}, \mathrm{CH}_{4}, \mathrm{OCS}, \mathrm{N}_{2} \mathrm{O}\right.$, and NO). Microbiol. Rev. 60:609-640.
10. Cronin, S.J., G. Lube, D.S. Dayudi, S. Sumarti, and S. Subrandiyo. 2013. Insights into the October-November 2010 Gunung Merapi eruption (Central Java, Indonesia) from the stratigraphy, volume and characteristics of its pyroclastic deposits. J. Volcanol. Geotherm. Res. 261:244-259.

11. Diaz-Herraiz, M., V. Jurado, S. Cueszva, L. Laiz, P. Pallecchi, P. Tiano, S. Sanchez-Moral, and C. Saiz-Jimenez. 2013. The actinobacterial colonization of Etruscan paintings. Sci. Rep. 3:1440.

12. Drudge, C.N., and L.A. Warren. 2014. Diurnal floc generation from neuston biofilms in two contrasting freshwater lakes. Environ. Sci. Technol. 48:10107-10115.

13. Eder, W., G. Wanner, W. Ludwig, H. Busse, F. Ziemke-Kägeler, and E. Lang. 2011. Description of Undibacterium oligocarboniphilum $\mathrm{sp.}$ nov., isolated from purified water, and Undibacterium pigrum strain CCUG 49012 as the type strain of Undibacterium parvum sp. nov., and emended descriptions of the genus Undibacterium and the species Undibacterium pigrum. Int. J. Syst. Evol. Microbiol. 61:384-391.

14. Eyice, O., M. Namura, Y. Chen, A. Mead, S. Samavedam, and H. Schäfer. 2015. SIP metagenomics identifies uncultivated Methylophilaceae as dimethylsulphide degrading bacteria in soil and lake sediment. ISME J. 9:2336-2348.

15. Fierer, N., M.A. Bradford, and R.B. Jackson. 2007. Toward an ecological classification of soil bacteria. Ecology 88:1354-1364.

16. Fujimura, R., Y. Sato, T. Nishizawa, K. Nanba, K. Oshima, M. Hattori, T. Kamijo, and H. Ohta. 2012. Analysis of early bacterial communities on volcanic deposits on the island of Miyake (MiyakeJima), Japan: a 6-year study at a fixed site. Microbes Environ. 27:1929.

17. Fujimura, R., S. Kim, Y. Sato, K. Oshima, M. Hattori, T. Kamijo, and H. Ohta. 2016. Unique pioneer microbial communities exposed to volcanic sulfur oxide. Sci. Rep. 6:19687.

18. Glöckner, F.O., H. Babenzien, and R. Amann. 1998. Phylogeny and identification in situ of Nevskia ramosa. Appl. Environ. Microbiol. 64:1895-1901.

19. Gomez-Alvarez, V., G.M. King, and K. Nüsslein. 2007. Comparative bacterial diversity in recent Hawaiian volcanic deposits of different ages. FEMS Microbiol. Ecol. 60:60-73.

20. Grayston, S.J., S.Q. Wang, C.D. Campbell, and A.C. Edwards. 1998. Selective influence of plant species on microbial diversity in the rhizosphere. Soil Biol. Biochem. 30:369-378.

21. Green, S.J., E. Inbar, F.C. Michel, Y. Hadar, and D. Minz. 2006. Succession of bacterial communities during early plant development: transition from seed to root and effect of compost amendment. Appl. Environ. Microbiol. 72:3975-3983.

22. Green, S.J., F.C. Michel, Jr., Y. Hadar, and D. Minz. 2007. Contrasting pattern of seed and root colonization by bacteria from the genus Chryseobacterium and from the family Oxalobacteracae. ISME J. 1:291-299.

23. Guo, Y., R. Fujimura, Y. Sato, W. Suda, S. Kim, K. Oshima, M. Hattori, T. Kamijo, K. Narisawa, and H. Ohta. 2014. Characterization of early microbial communities on volcanic deposits along a vegetation gradient on the island of Miyake, Japan. Microbes Environ. 29:38-49.

24. He, Z., X. Xie, S. Xiao, J. Liu, and G. Qiu. 2007. Microbial diversity of mine water at Zhong Tiaoshan copper mine, China. J. Basic Microbiol. 6:485-495.

25. Ibekwe, A.M., A.C. Kennedy, J.J. Halvorson, and C.H. Yang. 2007. Characterization of developing microbial communities in Mt. St. Helens pyroclastic substrate. Soil Biol. Biochem. 39:2496-2507.

26. Im, W.T., Q. Liu, J. Yang, M. Kim, S. Kim, S. Lee, and T. Yi. 2010. Panacagrimonas perspica gen. nov., sp. nov., a novel member of Gammaproteobacteria isolated from soil of ginseng field. J. Microbiol. 48:262-266.

27. Jackson, T.A. 2015. Weathering, secondary mineral genesis, and soil formation caused by lichens and mosses growing on granitic gneiss in a boreal forest environment. Geoderma 251-252:78-91.

28. Ji, M., C. Greening, I. Vanwonterghem, et al. 2017. Atmospheric trace gases support primary production in Antarctic desert surface soil. Nature 552:400-403.

29. Kalyuzhnaya, M.G., S. Bowerman, J.C. Lara, M.E. Lidstrom, and L. Christoserdava. 2006. Methylotenera mobilis gen. nov., sp. Methylotenera mobilis gen. nov., sp. nov., an obligately methylamine-utilizing bacterium within the family Methylophilaceae. Int. J. Syst. Evol. Microbiol. 56:2819-2823. 
30. Kalyuzhnaya, M.G., D.A.C. Beck, A. Vorobev, N. Smalley, D.D. Kunkel, M.E. Lidstrom, and L. Chistoserdova. 2012. Novel methylotrophic isolates from lake sediment, description of Methylotenera versatilis sp. nov. and emended description of the genus Methylotenera. Int. J. Syst. Evol. Microbiol. 62:106-111.

31. Kamagata, Y., R.R. Fulthorpe, K. Tamura, H. Takami, L.J. Forney, and J.M. Tiedje. 1997. Pristine environments harbor a new group of oligotrophic 2,4-dichlorophenoxyacetic acid-degrading bacteria. Appl. Environ. Microbiol. 63:2266-2272.

32. Kaštovská, K., J. Elster, M. Stibal, and H. Šantrůcková. 2005. Microbial assemblages in soil microbial succession after glacial retreat in Svalbard (high Arctic). Microb. Ecol. 50:396-407.

33. Kelly, L.C., C.S. Cockell, T. Thorsteinsson, V. Marteinsson, and J. Stevenson. 2014. Pioneer microbial communities of the Fimmvöròuháls lava flow, Eyjafjallajökull, Iceland. Microb. Ecol. 68:504-518.

34. Kim, S.W., W. Suda, S. Kim, K. Oshima, S. Fukuda, H. Ohno, H. Morita, and M. Hattori. 2013. Robustness of gut microbiota of healthy adults in response to probiotic intervention revealed by high-throughput pyrosequencing. DNA Res. 20:241-253.

35. King, G.M. 2003. Contributions of atmospheric CO and hydrogen uptake to microbial dynamics on recent Hawaiian volcanic deposits. Appl. Environ. Microbiol. 69:4067-4075.

36. King, G.M. 2007. Chemolithotrohic bacteria: distributions, functions and significance in volcanic environments. Microbes Environ. 22:309-319.

37. Knelman, J.E., T.M. Legg, S.P. O'Neill, C.L. Washenberger, A. González, C.C. Cleveland, and D.R. Nemergut. 2012. Bacterial community structure and function change in association with colonizer plants during early primary succession in a glacier fore field. Soil Biol. Biochem. 46:172-180.

38. Knight, R., P. Maxwell, A. Birmingham, et al. 2007. PyCogent: a toolkit for making sense from sequence. Genome Biol. 8:R171.

39. Kojima, H., and M. Fukui. 2011. Sulfuritalea hydrogenivorans gen. nov., sp. nov., a facultative autotroph isolated from a freshwater lake. Int. J. Syst. Evol. Microbiol. 61:1651-1655.

40. Kurata, S., T. Kanagawa, K. Yamada, M. Torimura, T. Yokomaku, Y. Kamagata, and R. Kurane. 2001. Fluorescent quenching-based quantitative detection of specific DNA/RNA using a BODIPY(R) FL-labeled probe or primer. Nucleic Acids Res. 29:e34.

41. Lagerstròm, A., M.-C. Nilsson, O. Zackrisson, and D.A. Wardle. 2007. Ecosystem input of nitrogen through biological fixation in feather mosses during ecosystem retrogression. Funct. Ecol. 21:1027-1033.

42. Land, V., M.L. Skotnicki, P.M. Selkirk, P. Broady, K.D. Adam, and J.A. Ninham. 2001. Dispersal of the moss Campylopus pyriformis on geothermal ground near the summits of Mount Erebus and Mount Melbourne, Victoria Land, Antarctica. Antarct. Sci. 13:280-285.

43. Lincoln, S.P., T.R. Fermor, and B.J. Tindall. 1999. Janthinobacterium agaricidamnosum sp. nov., a soft rot pathogen of Agaricus bisporus. Int. J. Syst. Evol. Microbiol. 49:1577-1589.

44. Lindo, Z., and A. Gonzalez. 2010. The bryosphere: an integral and influential component of the earth's biosphere. Ecosystems 13:612627.

45. Liu, J., W. Kong, G. Zhang, A. Khan, G. Guo, C. Zhu, X. Wei, S. Kang, and R.M. Morgan-Kiss. 2016. Diversity and succession of autotrophic microbial community in high-elevation soils along deglaciation chronosequence. FEMS Microbiol. Ecol. 92:fiw160.

46. Lu, H., R. Fujimura, Y. Sato, K. Nanba, T. Kamijo, and H. Ohta. 2008. Characterization of Herbaspirillum- and Limnobacter-related strain isolated from young volcanic deposits in Miyake-Jima island, Japan. Microbes Environ. 23:66-72.

47. Nara, K., H. Nakaya, B. Wu, Z. Zhou, and T. Hogetsu. 2003. Underground primary succession of ectomycorrhizal fungi in a volcanic desert on Mount Fuji. New Phytol. 159:743-756.

48. Navarrete, A.A., A.M. Venturini, K.M. Meyer, A.M. Klein, J.M. Tiedje, B.J.M. Bohannan, K. Nüsslein, S.M. Tsai, and J.L.M. Rodrigues. 2015. Differential response of Acidobacteria subgroups to forest-to-pasture conversion their biogeographic patterns western Brazilian Amazon. Front. Microbiol. 6:1443.

49. Nemergut, D.R., S.P. Anderson, C.C. Cleveland, A.E. Martin, E. Miller, A. Seimon, and S.K. Schmidt. 2007. Microbial community succession in an unvegetated, recently deglaciated soil. Microb. Ecol. $53: 110-122$.
50. Nishizawa, T., M. Komatsuzaki, N. Kaneko, and H. Ohta. 2008. Archaeal diversity of upland rice field soils assessed by the terminal restriction fragment length polymorphism method combined with real time quantitative-PCR and a clone library analysis. Microbes Environ. $23: 237-243$

51. Sato, Y., H. Nishihara, M. Yoshida, M. Watanabe, J.D. Rondal, and H. Ohta. 2004. Occurrence of hydrogen-oxidizing Ralstonia species as primary Microorganisms in the Mt. Pinatubo volcanic mudflow deposits. Soil Sci. Plant Nutr. 50:855-861.

52. Sato, Y., N. Hirofumi, M. Yoshida, M. Watanabe, J.D. Rondal, N. Rogelio, and H. Ohta. 2006. Cupriavidus pinatubonensis sp. nov. and Cupriavidus laharis sp. nov., novel hydrogen-oxidizing, facultatively chemolithotrophic bacteria isolated from volcanic mudflow deposits from Mt. Pinatubo in the Philippines. Int. J. Syst. Evol. Microbiol. 56:973-978.

53. Sato, Y., K. Hosokawa, R. Fujimura, T. Nishizawa, T. Kamijo, and H. Ohta. 2009. Nitrogenase activity (acetylene reduction) of an iron-oxidizing Leptospirillum strain cultured as a pioneer microbe from a recent volcanic deposit on Miyake-Jima, Japan. Microbes Environ. 24:291296.

54. Schmidt, S.K., S.C. Reed, D.R. Nemergut, et al. 2008. The earliest stages of ecosystem succession in high-elevation (5000 metres above sea level), recently deglaciated soils. Proc. Biol. Sci. 275:2793-2802.

55. Street, L.E., J-A. Subke, M. Sommerkorn, V. Sloan, H. Ducrotoy, G.K. Phoenix, and M. Williams. 2013. The role of mosses in carbon uptake and partitioning in arctic vegetation. New Phytol. 199:163175.

56. Summers, S., A.S. Whiteley, L.C. Kelly, and C.S. Cockell. 2013. Land coverage influences the bacterial community composition in the critical zone of a sub-Arctic basaltic environment. FEMS Microbiol. Ecol. 86:381-393.

57. Surono, M., P. Jousset, J. Pallister, et al. 2012. The 2010 explosive eruption of Java's Merapi volcano-a 100 years event. J. Volcanol. Geotherm. Res. 242:121-135.

58. Suyama, T., Y. Tokiwa, P. Ouichanpagdee, T. Kanagawa, and Y. Kamagata. 1998. Phylogenetic affiliation of soil bacteria that degrade aliphatic polyesters available commercially as biodegradable plastics. Appl. Environ. Microbiol. 64:5008-5011.

59. Tani, A., M. Akita, H. Murase, and K. Kimbara. 2011. Culturable bacteria in hydrophonic cultures of moss Racomitrum japonicum and their potential as biofertilizers for moss production. J. Biosci. Bioeng. 112:32-39.

60. Uroz, S., C. Calvaruso, M.P. Turpault, A. Sarniguet, W. de Boer, J.H.J. Leveau, and P. Frey-Klett. 2009. Efficient mineral weathering is a distinctive functional trait of the bacterial genus Collimonas. Soil Biol. Biochem. 41:21788-2186.

61. Uroz, S., C. Calvaruso, M.P. Turpault, and P. Frey-Klett. 2009. Mineral weathering by bacteria: ecology, actors, and mechanisms. Trends Microbiol. 17:378-387.

62. Watanabe, T., H. Kojima, and M. Fukui. 2015. Sulfuriferula multivorans gen. nov., sp. nov., isolated from a freshwater lake, reclassification of 'Thiobacillus plumbophilus' as Sulfuriferula plumbophilus sp. nov., and description of Sulfuricellaceae fam. nov. and Sulfuricellales ord. nov. Int. J. Syst. Evol. Microbiol. 65:1504-1508.

63. Watanabe, T., H. Kojima, and M. Fukui. 2016. Sulfuriferula thiophila sp. nov., a chemolithoautotrophic sulfur-oxidizing bacterium, and correction of the name Sulfuriferula plumbophilus to Sulfuriferula plumbiphila corrig. Int. J. Syst. Evol. Microbiol. 66:2041-2045.

64. Watts, S.F. 2000. The mass budgets of carbonyl sulfide, dimethyl sulfide, carbon disulfide and hydrogen sulfide. Atmos. Environ. 34:761-779.

65. Weber, C.F., and G.M. King. 2010. Distribution and diversity of carbon monoxide-oxidizing bacteria and bulk bacterial communities across a succession gradient on a Hawaiian volcanic deposit. Environ. Microbiol. $12: 1855-1867$.

66. Weber, C.F., and G.M. King. 2010. Quantification of Burkholderia coxL genes in Hawaiian volcanic deposits. Appl. Environ. Microbiol. 76:2212-2217.

67. Weber, C.F., and G.M. King. 2017. Volcanic Soils as sources of novel CO-oxidizing Paraburkholderia and Burkholderia: Paraburkholderia hiiakae sp. nov., Paraburkholderia metrosideri sp. nov., Paraburkholderia paradisi sp. nov., Paraburkholderia peleae sp. nov., and Burkholderia alpina sp. nov. a member of the Burkholderia cepacia complex. Front. Microbiol. 8:207. 
68. Wulaningsih, T., H. Humaida, A. Harijoko, and W. Koichiro. 2013. Major element and rare earth elements investigation of Merapi Volcano, Central Java, Indonesia. Procedia Earth Planet. Sci. 6:202211.

69. Yoshitake, S., M. Fujiyoshi, K. Watanabe, T. Masuzawa., T. Nakatsubo, and H. Koizumi. 2012. Successional changes in the soil microbial community along vegetation development sequence in a subalpine volcanic desert on Mount Fuji, Japan. Plant Soil 364:261-272.
70. Yoshitake, S., M. Uchida, Y. limura, T. Ohtsuka, and T. Nakatsubo. 2018. Soil microbial succession along a chronosequence on a High Arctic glacier foreland, Ny-Ålesund, Svalbard: 10 years' change. Polar Sci. 16:59-67.

71. Zhou, J., M.A. Bruns, and J.M. Tiedje. 1996. DNA recovery from soils of diverse composition. Appl. Environ. Microbiol. 62:316-322. 